811.163.41'366.582.4

811.163.41'367.625

https://doi.org/10.18485/msc.2018.47.1.ch2

Радоје Д. СИМИЋ*

Универзитет у Београду

Филолошки факултет
Оригинални научни рад

Примљен: 25. 10. 2017.

Прихваћен: 27. 12. 2017.

\title{
О АОРИСТУ ИМПЕРФЕКТИВНИХ ГЛАГОЛА И СРОДНИМ ПОЈАВАМА
}

\begin{abstract}
После знаменитих Маретићевих и Мусићевих истраживања о значењу и употреби глаголских времена - од свих облика аорист је постао најзначајнија и научне пажње највреднија тема. Посебно место у расправи има аорист имперфективних глагола. Аутор овог рада полази од Белићевих ставова и покушава да разреши проблем глаголског времена и вида уопште, посебно у значењу аориста имперфективних глагола.

Кључне речи: вид, време, аорист, имперфекат, перфектизација, глобализација.
\end{abstract}

\section{1. Увод}

1. Дуго је у науци о значењу глаголских облика вођена расправа о томе да ли је глаголско време самостална категорија или је зависна од вида. А. Белић мисли да временски облици своје значење чувају само у индикативној употреби, док га у релативу губе или своде на видско значење. После дуже расправе, од својих полазних, у по нечем екстремних позиција одустао је и сам Белић. Овде ћемо се осврнути на његова новија схватања. Он у контексту завршних лингвистичких испитивања тврди „да су глаголски вид и глаголско време две различне ствари иако се извесно видско значење може добити на основу употребе извесног глаголског значења у извесном времену..., исто онако као што се глаголи извесног видског значења могу употребити у једним временима, а у другима не могу, или као што се неки видски облик могао употребити за извесно временско значење када су им се временски облици, у извесној употреби, по значењу знатно приближили" (Белић 1998: 223). Развијајући своје мисли даље, Белић (1998: 229) преци-

*jelenajo@bitsyu.net 
зније формулише неке додатне моменте које сматра битним за разумевање односа вида и времена:

Ја мислим да ту треба разликовати три потпуно различна случаја: 1) када се глаголи извесног видског значења које чини део њихове основе употребљавају у неком времену које допушта да се њихово значење може комбиновати са временским значењем дане категорије (каква је напр. искључива употреба трајних глагола у [индикативном] презенту...); 2) када се значење вида добија помоћу временског значења и 3) када се облик вида употребљава за временско значење (исп. случајеве код футура). Ја мислим да други случај претстављају индоевропски перфекат и индоевропски аорист... Чим аорист значи моментаност ('Punktualisierung') радње, без икакве претставе о њену трајању..., онда је јасно да се то могло добити једино слагањем претериталности са тренутношћу глаголске радње...

Тачне Белићеве констатације праћене су не сасвим тачним интерпретацијама. Наиме, није реч о укрштању вида и времена већ о појавама у семантици неких претериталних, а и других облика који у великој мери подсећају на словенски вид и које Белић обележава термином 'перфектизација'. Али ми ћемо поставити тезу да се, у ствари, не ради о категорији вида у правом смислу како се на вид гледа у српској науци о језику, већ о појавама блиским виду. И која није у вези само са аористом (и перфектом) већ и са неким другим облицима.

2. Овде је згодно место да поменемо и мишљење И. Грицкат.

2.1. У студији посвећеној футуру другом (Грицкат 1956) ауторка између осталог примећује да овај облик (и не само он) каткада за собом повлачи 'перфектизацију' несвршених глагола. „Реченицу: 'Кад будеш ишао, не заборави да понесеш доглед', морамо протумачити овако: 'Кад будеш пошао', јер понети неку ствар човек може само на почетку путовања, а не у току. У преводу на неки други језик који такође познаје два вида ова особеност се запажа сасвим јасно. Тако, напр., у руском језику... ова би реченица гласила: Когда ты пооедеш, не забудь взять...”.

У таквој употреби може се, у извесном смислу, осетити приближавање перфективном виду код глагола иначе имперфективних. Разуме се, глаголи ту не постају перфективни; само се целокупни контекст даје лако превести, интерпретирати помоћу перфективног глагола са значењем наилажења, настајања. И то није ретка појава у српскохрватском језику. Наше језичко осећање мора понекад уложити чак и известан напор, ако се тако може рећи, да, напр., реченицу 'ако пролетос будете зидали кућу' не протумачи као 'ако станете да зидате', 'ако дође до тога да зидате' и сл. ...Стога је разумљиво што се имперфективним глаголима овде формално не мења вид, што ми немамо појаву граматичке перфектизације. Овде се осећа - и то не увек... - нешто друго, наилажење целе радње, њена појава; на њу се и даље мисли у њеној трајности, само што се наглашава да вршење треба да дође, да се оствари.

Суптилна ауторкина запажања помућена су једним споредним моментом који она није приметила. А ради се о томе што је футур други 'будуће' време, па је постериорност у односу на неки ослонац, стварни или фингирани, увек у њему присутна. Ако апстрахујемо тај моменат, И. Грицкат ће бити сасвим у праву, али она није смогла појмовља да то објасни. Данашњи истраживачи одустају од 'извршености', која није сасвим погођен опис ове појаве, него (у вези не са футуром другим, него заправо са аористом) инсистирају на особе- 
ности коју Грицкат наслућује и помиње у летимичном додиру њене мисли са темом - а то је означавање 'целе радње'.

2.2. Додаћемо и шира запажања ауторкина која бацају светло на вид и време српскога глагола уопште, а не само на питање футура другог у вези с тим:

Треба напоменути да се такво разумевање глаголске радње јавља понекад, у ограниченом броју случајева, и у вези с обичним футуром. 'Ти ћеш ићи' често значи нешто што је блиско значењу 'Ти ћеш поћи'. 'Мој брат ће већ сутра путовати на море, а ја тек кроз недељу дана'; мисли се: 'Брат ће поћи, кренути...' (руски превод би гласио: 'Мой брат поедет завтра', а никако 'будет ехать'). Међутим у прошлом времену, у истом смислу, тј. у смислу поласка, не би се рекло 'мој брат је јуче ищиа на море' него само 'отпутовао', 'отишао', 'кренуо'.

Тачно. Али ваља додати да 'Мој брат је ишао на море' може значити и комплетан догађај, тј. 'целину радње' - када обухвата и одлазак на море, и боравак тамо, и повратак с мора! Иако обухвата много дужи временски размак од самог поласка, 'ишао је' у некој перспективи подлеже 'перфектизацији', или боље 'комплетизацији': означавању догађаја као јединствене целине. И то је проблем за себе који заслужује научну пажњу и којем је посвећен овдашњи наш рад у широј верзији његовој, а који ће овде бити изложен укратко.

3. J. Вуковић (1967: 290) једном приликом, расправљајући о сличним питањима са П. Ивићем, каже да је „П. Ивић сасвим лепо осетио радњу исказану имперфектом као процес, сам процес - у ствари, и како одатле треба полазити да би се његова радња најлакше могла специфицирати”.

Међутим, и Ивић нас мора довести у забуну кад... каже: 'Стога није погрешно рећи да је простим претериталним временима радња захваћена као збивање догађаја, процес (ако под тим подразумевамо нешто што је везано за одређено време и околности у њему), а у перфекту као го факат, податак' (ЈФ XX, стр. 258). А пре тога, кад је реч о једној разлици употребе аориста и имперфекта (уз прилог доста), читамо: 'У таквим примерима имперфект не може доћи због тога што он значи паралелизам са ситуацијом у прошлости, ситуацијом које више нема (тада). Уосталом, овде је битно да се не мисли на време трајања радње, на њену слику, него на чисту радњу као такву, на њено вршење или невршење. У питању је радња као факат, мишљење говорног лица о томе факту' (стр. 256). Не можемо никако... ову радњу схватити као процес, нити се ту могу наћи икакви диференцијални моменти између аориста и перфекта. То је једно. А друго је, радња као факат слаже се за идентификовање перфекта, али колико она одговара аористу, не може се то разумети из оваквог начина формулисања мисли.

И поред контроверзе у Ивићевим објашњењима - на једној страни код аориста се „не мисли на време трајања радње, на њену слику”, а на другој се аорист сматра обликом који значи догађаје у одређено време (у 'доживљеној прошлости') - Ивићу се ипак не може оспорити тачност тврдње да аорист несвршених глагола по правилу упућује на 'радњу као факат', дакле 'комплетан догађај'. Сама ова контроверза представља теоријску загонетку коју би ваљало анализом грађе некако разрешити, и коју ћемо покушати у овом раду да разрешимо, али она не смета да прихватимо мисао о 'комплетизацијском' или 'глобализацијском' смислу аориста као тачну. У сваком случају, неспојивост 'комплетивности' и тзв. 'доживљености радње' у значењу аориста - коју заправо брани Вуковић - ипак је дезавуисана стварним значењем овог облика. 
4. Пратићемо сада Стевановићеву расправу, коме је такође стварно стало до одбране 'доживљености', тј. актуелности догађаја у одређеном временском моменту, временској ситуацији или размаку. Критикујући мишљења својих претходника у испитивању овог облика, Стевановић (1991: 635) каже:

Стојановићево мишљење, - према коме и аорист несвршених глагола означава само тренутак свршетка радње искључује се... видом тих глагола, који значи трајање њима исказане радње у сваком облику, па и у аористу... Ни ово схватање значења аориста имперфективних глагола, дакле, не може [се] прихватити зато што се у њему инсистира на свршености радње, коју ипак не можемо негирати у извесним случајевима, али која, колико ни извршеност, није битна за ово глаголско време несвршених глагола. Нарочито треба нагласити да, када би се значење аориста несвршених глагола сводило на извршеност, по Мусићу, или на свршеност, по Стојановићу, то би значило да се то значење овога глаголског времена своди на значење вида, што иначе не мисле ни Мусић ни Стојановић.

Аорист по Стевановићу (1991: 631) „означава радње које су се вршиле или извршиле у прошлости, пре тренутка говора". После дуже расправе у којој наводи ранија мишљења, о имперфективном аористу Стевановић (1991: 633-639) на крају закључује: „Функције аориста несвршених глагола... не претпостављају никакво истицање прекида, иако можда изгледа да се без тога овај аорист подудара са значењем имперфекта, како је то мислио и изрично тврдио Т. Маретић...”.

Међутим, и ако претпоставимо да се аористом несвршених глагола означава вршење радње у прошлости, што је свакако основно његово значење, то не значи да се та два времена подударају својим значењима, иако је у функцији имперфекта као глаголског времена баш то најзначајније... Аористом несвршених глагола се означава вршење радње за једно одређено време у прошлости (635) (нпр.: - Аргатовах три године дана, / и ја вукох дрвље и камење; - Капетан баци уже момцима, који се чудише његову послу).

Даље: „...аорист имперфективних глагола, већ по томе што је несвршен, не може значити извршење радње, мада се њим неки пут означава радња која се цела извршила: ’Аргатовах три године дана'... не значи да је онај коме се аргатовање приписује ту радњу извршио до краја, него само да ју је вршио једно одређено време (овде је, штавише, означено и колико - не, наравно, самим глаголским обликом, већ временском одредбом 'три године дана'). Тако исто ни у примеру: '...они се чудише његову послу... - не може бити ни говора о потпуној извршености дотичне радње, односно завршености стања које се казује односним глаголским обликом, него се само констатује да су они којима се ово приписује једно време у одређеној прошлости били у стању које се означава аористом 'чудише се"” (Стевановић 1991: 634-635). Међутим, Стевановићева дефиниција о 'радњи' која се вршила, или 'стању' „које се означава аористом” у 'одређеној прошлости' - без инсистирања на 'завршености' - означава и имперфекат, те би се овим потрла граница између ова два облика, и ми бисмо се нашли на Маретићевим позицијама!? Тиме загонетка о којој горе говорасмо није решена, него је постала акутна.

5. Значајни проблеми које пред истраживаче поставља однос глаголског вида и времена у овом правцу посматран могли би се после читања прегледаних радова описати на следећи начин. 
a) Временска оријентација глаголских личних облика у начелу је независна од глаголског вида (вид је „унутрашње време” глаголских речи - А. Белић).

б) Али ипак су неки облици 'селективни'1 у односу на видска значења глагола (имперфекат је нпр. комбинабилан само са имперфективним глаголским основама, док аорист претежно 'бира' перфективни вид). Горе је већ скренута пажња на тај моменат, који у нашој науци није остао незапажен, али је остао нерешен. Бацићемо стога још један поглед на ова питања у целини.

в) Главни проблем отвара се са склоношћу аориста да за комбиновање са имперфективним глаголима постави услов специфичне 'перфектизације' (одн. 'комплетизације', боље 'глобализације', јер аорист имперфективних глагола по свему судећи на значи 'довршење' нити 'свршетак' процеса, већ се он „сагледава у целини свога постојања”. - Танасић 2005: 345-476) или сл. Али видећемо - као што је у уводним напоменама и најављено - да овај облик није једини који се каткада тако понаша.

в1) Перфектизацији су пре свега склони двовидски глаголи: - „Е побратиме, сад да се дарујемо, ја ћу теби даровати снагу и благо, а ти мене за оба ова дара само своју душу”. Ови човјек премда је био опак, опет помисли хоће ли дати своју душу, али га страх нагна, те се дароваме (Вук 1969б: 139). - И сви људи... крстише се крштењем Јовановијем (Вук 1969а: 125).

в2) Али рекли смо већ да таквом поступку подлежу и imperfectiva tantum: - Чоек... оде дома и покаја се и као прави Хришћанин до дубоке старости живље (Вук 1969б: 140. - И људи видећи чудише се и хвалише Бога, који је дао власт такву људима (Вук 1969а: 32).

(1) Први пример садржи вањско ограничење глаголске радње у виду адвербијала 'до дубоке своје старости', те се тај моменат може узети за критериј 'перфектизације'.

(2) Други случај не садржи такво ограничење, али ипак 'чудише се' и 'хвалише' не упућују на временски отворене случајеве, већ на својеврстан начин обухватају радњу као целину. Танасићева мисао да се радње аориста „сагледавају у целини свога постојања” (Танасић 2005: 424 и д.) мислимо да је добро формулисана као дефиниција оваквих случајева.

в3) Но могућност да се радња „сагледава у целини свога постојања” нити je, рекосмо горе, ограничена само на аорист, нити се само њега тиче. Тиме се цео проблем показује компликованијим него што на први поглед изгледа.

У првом нашем случају, наиме, поред аориста 'дарива' садржана су још два облика истог глагола „да се дарујемо, ја ћу теби даровати снагу и благо”. Оба означавају једнократни поступак чије трајање није обележено нити је видно као саставни елеменат семантике облика. Радње се и овде „сагледавају у целини свога постојања".

${ }^{1} \mathrm{O}$ термину 'селективност' и другим проблемима које отвара тема о аористу и сл., в. Станојевић 2012, Арсенијевић 2013, Станојевић 2014. 
в4) Погледаћемо и следеће примере:

- Кад већ виде, да друкчије не може бити, онда цар пошаље једног свог везира (Вук 1969б: 25) - Кад он све чује, ражали му се здраво... (Вук 1969б: 174).

- Кад ујутру устане, а оно виноград посађен; друго јутро - листао - до седам дана било већ грожђе зрело... (Вук 1969б: 114). - ...намисли да остави мужа и да бјежи овоме другоме (Вук 1969б: 195).

(1) Презенти двовидских глагола 'виде' и 'чује' у нашим примерима означавају перфективне радње (за разлику нпр. од: - ...теби је до јела, а не видиш где газда хоће да умре!).

(2) Слично значење имају и лексички имперфективни глаголи 'листати' и 'бјежати', један употребљен у перфекту, а други у презенту.

Уведени смо у проблематику необичних значења временских глаголских облика, који у неким случајевима подразумевају процес видске транспозиције, 'перфектизације', односно боље: 'глобализације' значења глагола. Да бисмо дошли до решења проблема, очито је потребно прегледати нешто ширу грађу и повести расправу о њој. У широј верзији овога рада узели смо три различите стилске формације: Вуков превод 'Новог завјета', Вукове 'Српске народне приповијетке', и 'Приповетке' Л. Лазаревића. Но због ограничености простора овде смо могли приказати само грађу из Лазаревићевих приповедака, па је утолико убедљивост наших налаза умањена.

\section{2. Грађа (имперфективни аорист и имперфекат у приповеткама Лазе К. Лазаревића)}

1. Већ досад анализирана грађа показује извесну правилност у понашању не само аориста, већ и других неких облика. Та правилност тиче се приказа радње из даљег угла као целовитог догађаја, а изблиза као процеса у току. Изузетак чини аорист, који из ближе перспективе радњу представља управо као целовит догађај. Проверићемо наше налазе тако што ћемо анализирати још и грађу из приповедака Лазе К. Лазаревића. Опште је мишљење да је Лаза К. Лазаревић писац чијем се језичком осећању не може ништа приговорити, као ни његову уметничком генију. Познато је исто тако да је он у неким питањима језичких вредности и језичке употребе, сем за народном речи, строго следио за језичком праксом Вука Ст. Караџића. Сем осталог - то се може устврдити и за употребу глаголских временских облика, посебно аориста и имперфекта. У овом поглављу нашег рада изложићемо грађу само ова два облика у обиму који дозвољава простор нашег рада.

2. Висока фреквенција пређашњих времена у Лазаревићеву тексту сведочи заправо о његовом избору језичких узора и стила којим је писао своје приче. По томе, а и по избору тема, схватањима која је испољавао у свом стваралаштву и моралним порукама - очигледно је да је Лаза Лазаревић у себи носио дубоко религиозна осећања, као и високо поштовање не према Вукову делу и Вукову и Даничићеву језику као таквом, већ заправо према 
религијским списима, то јест конкретно према Светом писму, које се трудио да копира у многим правцима. Вратићемо се језичком изразу, и навешћемо нпр. опис двојице јунака приповетке „Све ће то народ позлатити”:

Замало још, и свет се сасвим разиђе. Осим слугу и чиновника паробродских на обали стајаху само још два човека... Онај у фесу, Благоје казанџија - цео дан нестрпљиво ходаше: сваки час запиткиваше кога по штогод; обрташе се непрестано...; улажаше у станичну гостионицу, и чисто као да ће одоцнити, истрчаваше, упирући поглед далеко преко Саве. Његово лепо избријано, чисто лице... стајаше некако у контрасту с маленим плавим, ведрим очима које живо, па ипак с поуздањем, скакаше с једног предмета на други.

Сваки час је запиткивао..., на што му момци и агент, са урођеним господством страних држављана, врло кратко и осорно одговараще 144-145.

Капетан, пак, по имену Танасије Јеличић, стајаше готово цео дан на истом месту... Лице му беше окренуто страни с које лађа долази, а очи уморно и стално блудише око тога места... На његову лицу не беше онога хероичнога изгледа...; све то издаваше господина и гејака... 145.

a) Наведени редови показују висок ниво приповедног интензитета са врло необичним унутрашњим односима. (1) Почетни аорист '(Замало још и свет) се (сасвим) разиђе' као да обележава дубок обрт ситуације: живост која је владала на 'пристаништу' наједном престаје, и настаје мир: 'Осим слугу и чиновника паробродских на обали стајаху само још два човека'. Али знатни таласи оног немира из претходне слике преливају се и на ову коју пратимо. (2) Између осталог, томе доприноси контраст међу двојицом актера: узнемиреним и устрепталим 'Благојем казанџијом', кога не држи место и који не престаје трчкарати около и запиткивати људе о доласку лађе; и мирног и забринутог 'капетана', усредсређеног на 'страну с које лађа долази'. Мноштво имперфеката сугерира унутрашње кретање које се на површини показује само као напон који најављује долазак значајних догађаја.

б) Имперфекти 'стајаху', 'стајаше', 'беше' у тону су са сугерираним миром описане слике, али актуелност радње на коју упућују чини да интензитет излагања одржава висок ниво. Да се подсетимо, имперфекат осветљава радњу као процес који управо тече у ситуацији на коју се односи (старији истраживачи говоре о 'доживљености', а савременији о актуелности, 'изненадности' или сл., и код аориста и код имперфекта).

в) Посебно истакнути облици јесу имперфективни аористи. Већ смо се сусрели са квалификацијом њиховом као облика за 'перфектизацију', односно 'глобализацију', 'комплетизацију' радње итд. И заиста, према нпр. имперфекту 'стајаше' - као облику за обележавање актуелног процеса у трајању, аорист 'скакаше' инсистира на самој ситуацији, и ограничава трајање радње на њу саму. Исто такав је однос аориста 'блудише' према имперфекту 'стајаше'. Перфекат 'је запиткивао' неутралан је што се тиче актуелности радње коју означава, али на неки начин је сличан имперфекту што се тиче трајања њеног: не упућује на целовитост дешавања. Аорист 'одговараше', напротив, нема уграђених 'сензора' за индикацију дешавања ван ситуације на коју се односи, па се тај факат прима као ограничавајући моменат, као приказ радње у целости њеној. Тиме је донекле поремећена атмосфера сталности, коју у ситуацију уносе имперфекти: узајамна дискретност аористних садржаја до- 
живљава се као импостација прекида и код имперфективних глагола као низ догађаја који се у убрзаном темпу приче међусобно смењују.

3. Имперфективни аорист није оличен само у наведеним примерима, већ се код Лазаревића (1963) јавља у већем броју случајева:

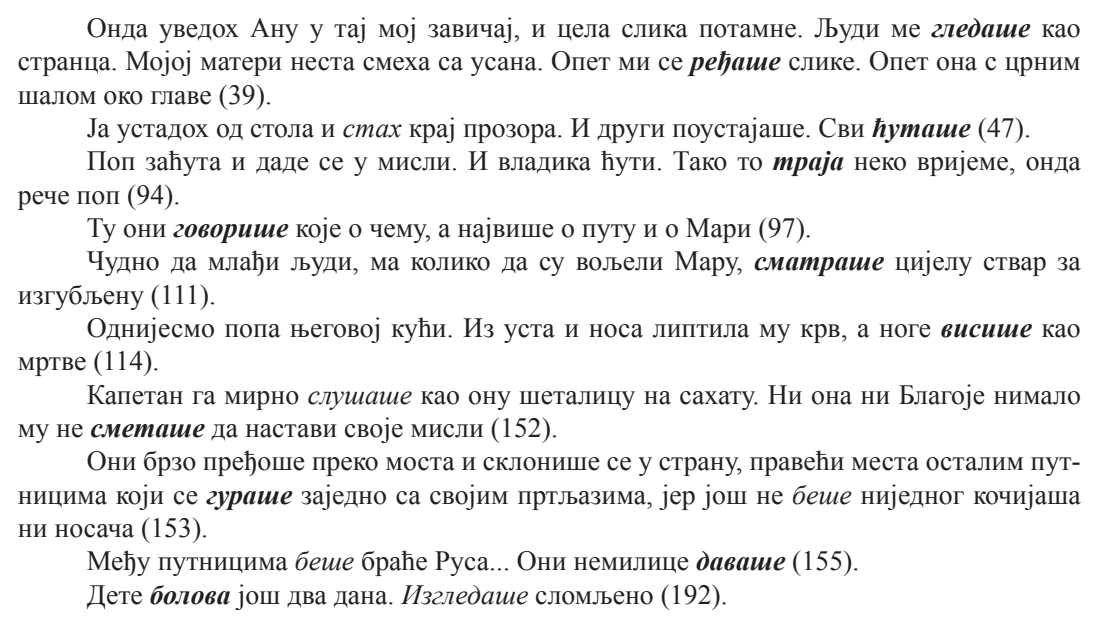

Свуда је имперфективни аорист истога значења: има 'глобализацијску' нијансу у означавању радње на коју се односи. То се најбоље увиђа конфронтацијом аориста и имперфекта у истој ситуацији.

(1) Нпр. у првом случају, у 'тамној слици' завичаја, искази: Људи ме гледаше, - Опет ми се ређаше слике, - Сви Ћуташе - у поређењу са: - Људи ме гледаху, - Опет ми се peђaxy слике, - Сви ћymaxy - предочавају две различите ситуације: имперфекти 'гледаху' 'ређаху се', 'ћутаху' попуњавају читав временски простор и преливају се преко његових оквира, док пак аористи 'гледаше', 'ређаше се', 'ћуташе' остављају утисак заобљености догађаја унутар тог оквира, не допирући до његових граница.

(2) Аорист 'траја' у другом наведеном примеру и сам је ограничен временском одредбом 'неко вријеме', па је сувишно о њему говорити јер је неутралисано за нас најбитније семантичко обележје његово и прекривено границама које поставља адвербијал.

(3) Непотребно је даље се удубљивати у значење исказних форми јер полазећи од анализираних свак може уочити утврђену особеност аориста. Указаћемо стога само још на претпоследњи пример, у којем прилог 'немилосрдно' врло појачава интензитет излагања, па бисмо очекивали и његово разливање на временској оси. Али 'немилосрдно даваше' - кад овај обрт упоредимо са имперфекатским 'немилосрдно даваху' - без сумње заобљује радњу као целину која и овде не достиже границе ситуације.

4. Питање је само у којој је мери заправо оправдано уносити ту нијансу у смисао описа - колико је тј., и где је на месту употреба аориста уместо имперфекта (В.: Ту они говорише/говораху које о чему... - или сл.). Али питање нормативности облика нити овде треба постављати нити га је оправдано уоп- 
ште постављати у вези са текстом Л. Лазаревића. Но Лазаревић заправо није сам у таквом односу према глаголским облицима. И Св. Ранковић, свештеник по позиву, умео је на исти начин служити се имперфективним аористом, о чему сведочи следећи (благо стилизован) навод:

Беше се искупило доста народа. Попа већ позвао одборнике у заседање, па одлучује са њима ко ће шта носити. Крст дадоше од прве кметову синчићу, ма око барјака се никако не могоше погодити. Извириваше сви редом на прозор да разгледају кандидате који су се ту поређали, па напослетку изиђоше напоље. Момчадија пребледела, па нико не дише; све упрло очи у попу, који разгледа једнога по једнога, па види се, ни сам не могаше да се одлучи куда ће (Ранковић 1958: 28).

а) Аорист 'извириваше' својим садржајем ситуиран је у ситуацији чију почетну временску границу чини плусквамперфекат 'беше се скупило (доста народа)', који је ту границу оштро оцртао упућујући да је догађај који означава претходио ситуацији, а да је резултат ('окупљен народ') део ситуације. Завршну пак границу обележава клаузална структура 'па напослетку изиђоше напоље'.

(1) Аорист не досеже ни једну ни другу границу, већ свој садржај представља као заобљену целину унутар ситуације.

(2) Врло је поучна чињеница да овде не би био прихватљив имперфекат 'извириваху'! Разлог је што је систем односа створених приповедним поступцима тако чврст да у овој прилици не допушта могућност преливања 'разгледања' преко граница ситуације, што имперфекат нужно подразумева.

б) Други случај - имперфекат 'разгледа', употребљен је у ситуацији која има почетну границу, исту ону којом се завршава претходна: 'па напослетку...', а према крају је отворена. Имперфекат 'не могаше' већ указује на могућност употребе таквог облика, а замена имперфективног аориста 'разгледа' имперфектом 'разгледаше' говори да је могуће преливање његовог садржаја преко завршне фазе дате ситуација (исп.: 'да се одлучи куда ће'). Но аорист ипак собом ограничава свој садржај заокружујући га у јединствену целину, док имперфекат те особености нема.

\section{3. Закључне напомене}

1. Старији синтаксичари су приметили да аорист имперфективних глагола има специфично значење, и објашњавали су га као 'перфектизацију', али је било тешко помирити оно што аорист значи са 'пунктуалном' теоријом вида, како се показало у анализи грађе; већи су изгледи на успех ако у објашњењу значења аориста пођемо од 'глобализацијског' принципа.

2. Но сем аориста, 'глобализацијску' нијансу значења показују и неки други облици, свакако употребљени у посебним ситуацијама. Посебност аориста лежи у томе што он 'глобализацијски' смисао комбинује са актуелношћу ('доживљеношћу') догађаја који означава.

3. Ми смо се у овом раду ограничили само на проблем аориста, и утврдили смо да имперфективни аорист у језику Л. Лазаревића и Св. Ранковића 
- кад се упореди са имперфектом у истим позицијама упућује на радњу „као целовит догађај" који собом достиже границе ситуације (то се може постићи тек употребом одговарајућих адвербијала: 'три године', 'до поноћи' или сл.).

\section{ИЗВОРИ}

Вук 1969а: Вук Ст. Караџић, Нови завјет Господа натега Исуса Христа, Београд: Просвета.

Вук 1969б: Вук Ст. Караџић, Српске народне приповијетке, Београд: Просвета.

Лазаревић 1963: Л. Лазаревић, Све ће то народ позлатити, Приповетке, Београд: Просвета.

Ранковић 1958: Св. Ранковић, Горски иุар, Београд: Нолит.

\section{ЛИТЕРАТУРА}

Арсенијевић 2013: Б. Арсенијевић, Временско и аспектуално значење аориста, Српски језик, XVIII, 253-261.

Белић 1998: А. Белић, Општа лингвистика, Изабрана дела, 1, Београд: Завод за уџбенике.

Белић 2000а: А. Белић, О синтаксичком индикативу и 'релативу'. О различитим питањима савременог језика, Изабрана дела, 12, Београд: Завод за уџбенике.

Белић 2000б: А: Белић, О употреби времена у српскохрватском језику. О различитим питањима савременог језика, Изабрана дела, 13, Београд: Завод за уџбенике.

Вуковић 1967: Ј. Вуковић, Синтакса глагола, Сарајево: Завод за издавање уџбеника.

Грицкат 1956: И. Грицкат, О неким особинама футура II (футура егзактног), Нам језик, 8, 88-105.

Грицкат 1957-1958: И. Грицкат, О неким видским особеностима српскохрватског глагола, Јужнословенски филолог, XX, 307-332.

Грицкат 1966-1967: И. Грицкат, Префиксација као средство граматичке (чисте) перфектизације, Јужснословенски филолог, XXVII/1-2, 185-223.

Станојевић 2007: В. Станојевић, Аорист у српском и француском језику, Научни састанак слависта у Вукове дане, 36/1, 123-135.

Станојевић 2013: В. Станојевић, Резултативност у садашњости у француском и српском језику, Српски језик, XVIII, 213-227.

Станојевић 2014: В. Станојевић, О аористу опет и с поводом, Српски језик, XIX, 117-132.

Стевановић 1966-1967: М. Стевановић, Значење аориста имперфективних глагола, Јужнословенски филолог, XXVII/1-2. 
Стевановић 1991: М. Стевановић, Савремени српскохрватски језик II, 5. изд., Београд: Научна књига.

Танасић 2005: С. Танасић, Синтакса глагола, у књ.: Пипер и др., 345-476.

Пипер и др. 2005: П. Пипер и др., Синтакса савременога српског језика, Институт за српски језик САНУ, Матица српска.

Radoje D. Simić

ON THE AORIST OF THE IMPERFECTIVE VERBS AND OTHER RELATED

QUESTIONS OF THE VERBS

\section{Summary}

The author starts from Belich's attitudes and tries to solve the problem of the verbal time and vision in general, especially in the sense of the imperfective verbs.

In order to explain the meaning of Aorist we have proceeded from the "globalizing" principle. Apart from Aorist there are other forms revealing globalizing nuance of meaning, the ones used on special occasions. Aorist is exceptional in that respect that it combines "globalizing" sense with the current events ("experienced") that it denotes. It has been stated in this paper that the imperfective Aorist in the language of L. Lazarevic and Sv. Rankovic - when compared to the imperfect in the same positions refers to the action as "a global event" which in itself reaches the borders of the situation (which can be achieved only by using adequate adverbials such as: "three years", "by midnight".

Key words: aspect, time, aorist, I mperfection, perfection, globalization 